Canadian University Music Review

Canadian University Music Review

Revue de musique des universités canadiennes

\title{
An Early Eighteenth-Century Discussion of Musical Acoustics by Étienne Loulié
}

\section{Richard Semmens}

Numéro 2, 1981

URI : https://id.erudit.org/iderudit/1013750ar

DOI : https://doi.org/10.7202/1013750ar

Aller au sommaire du numéro

Éditeur(s)

Canadian University Music Society / Société de musique des universités canadiennes

ISSN

0710-0353 (imprimé)

2291-2436 (numérique)

Découvrir la revue

Citer cet article

Semmens, R. (1981). An Early Eighteenth-Century Discussion of Musical Acoustics by Étienne Loulié. Canadian University Music Review / Revue de musique des universités canadiennes, (2), 177-206.

https://doi.org/10.7202/1013750ar

All Rights Reserved (C Canadian University Music Society / Société de musique des universités canadiennes, 1981
Ce document est protégé par la loi sur le droit d'auteur. L'utilisation des services d'Érudit (y compris la reproduction) est assujettie à sa politique d'utilisation que vous pouvez consulter en ligne.

https://apropos.erudit.org/fr/usagers/politique-dutilisation/ 


\section{AN EARLY EIGHTEENTH-CENTURY DISCUSSION OF MUSICAL ACOUSTICS BY ÉTIENNE LOULIÉ}

\section{Richard Semmens}

The seventeenth century was a period of dynamic discovery in the physical sciences. The studies of astronomy and dynamics underwent perhaps the most noteworthy metamorphoses (see Toulmin 1961:4). In astronomy, the improvement of the telescope by Galileo Galilei provided an alarming confirmation of Copernicus's theory, On the Revolution of the Celestial Orbs (1543). When coupled with the laws of motion and the theory of gravitation of Isaac Newton, this shattered man's ideas about the ordered relations between the earth and the cosmos.

Similar re-alignments in thinking were in evidence in the science of music. The humanistic Renaissance ideals in music which were codified and transmitted to the seventeenth century by such writers as Gioseffe Zarlino, in his Istitutione armoniche (Venice, 1558), were subjected to considerable revision. We might observe Zarlino's discussion of the senario for an example of this tendency. In the senario the decreasing perfection of the first three consonances was symbolically represented in the progression of their ratios: 2:1 for the octave; $3: 2$ for the fifth; and $4: 3$ for the fourth - the further removed from the unity, 1 , the less perfect the ratio, and hence the interval it represented. The experiments of Vincenzo Galilei, described in an essay entitled, "A Particular Discourse Concerning the Diversity of the Ratios of the Octave" (ca. 158990), and of Marin Mersenne, articulated in his Traité de l'harmonie universelle (Paris, 1627) showed that the perfect consonances could be represented accurately by ratios other than the superparticular ones (that is of the class $\frac{n+1}{n}$ (see Palisca 1961: $129 \mathrm{ff}$.). Thus an octave could have a ratio of 4:1, a 
fifth one of 9:4 and a fourth one of 16:9 if string tensions were being described rather than string lengths. In terms of arithmetic alone, then, a fifth no longer could be considered more perfect than, say, a minor sixth. It was with this newer, empirical approach that the science of modern acoustics evolved.

This paper will examine a series of short essays on various subjects in the realm of musical acoustics by the French theorist Étienne Loulié (d. ca. 1707). A large corpus of writings concerning music was left unpublished by Loulié at his death, was willed to his close friend Sébastien de Brossard (1654-1730), and subsequently donated by Brossard to the Bibliothèque du Roi in 1725. These manuscripts are preserved in three separatelybound volumes in the Bibliothèque Nationale in Paris - Fonds Français, n.a. 4686, 6355, and 6356. Loulié's essays on acoustics comprise twenty-seven folios (f. $142 \mathrm{r}-168 \mathrm{v}$ ) of Ms. $6355 .{ }^{1}$ They represent a more speculative aspect of Loulié's writings, and include brief discussions of musical intervals, resonance, sound in general, the mathematical derivation of interval ratios, beats, and tuning. Before examining these topics in some detail, it will be useful to summarize the work in the field of musical acoustics of Loulié's contemporaries and of his immediate predecessors.

At the beginning of his "Système générale des intervalles des sons, et son application à tous les instruments de musique," Joseph Sauveur (1653-1716) writes:

I have thus believed that there is a science superior to music, which I have called "Acoustics," which has as its object sound in general, whereas music has as its object sound in so far as it is agreeable to the hearing. To treat this science in the manner of others, especially of optics, to which it bears great resemblance, it would be necessary to explain the nature of sound, the organ of hearing, and, in detail, all the properties of sound, in order to infer from them the causes of the agreement and the disagreement of sounds which serve as the object of music and harmony; and finally the apparatus, not only of music in particular, but also of acoustics in general (Sauveur 1736:403-04). ${ }^{2}$

With this brief statement, Sauveur not only established a term which could be applied to the study of the phenomenon of sound, but he also laid down certain guidelines for the system- 
atic study of this science. Besides comparing acoustics to the science of optics, Sauveur hints at the three-fold division of the study of acoustics which, later in the eighteenth and nineteenth centuries, was to become standard: the production of sound; the propagation of sound; the reception of sound (see Lindsay 1945: xii).

There can be little doubt in this and in other writings that Sauveur exerted a steadying influence on the future work of acousticians, ${ }^{3}$ and that his work represents an important point of departure for subsequent eighteenth-century writers in this field, such as Brook Taylor (1713: 26-32), Leonhard Euler, (1727), Jean d'Alembert (1747: 214-19), and Joseph Lagrange (1759). On the other hand, Sauveur may be seen as the culmination of a century of dynamic discovery concerning the physical nature of sound. Among the Frenchmen who clearly influenced Sauveur's thinking on the subject are René Descartes (ca. 1618), Marin Mersenne, especially his Cogita physico mathematica (1644), Claude Perrault, especially "Du Bruit" and "De la musique des anciens" from his Essais de physique (1680), Jacques Rouhault (1671), and Philippe de la Hire (1730: 330-50). Sauveur frequently worked with the last three-named at meetings of the Académie Royale des Sciences, where many questions concerning acoustics were discussed (see Scherchen 1950, passim).

To the list of writers whom Sauveur influenced must be added the name Étienne Loulié. Loulié never uses the term acoustics; neither does he explore in any depth the realm of non-musical sound. Nevertheless, it is clear that he understood much of what was new in the work of Sauveur and his contemporaries.

Historical perspective in the field of acoustics is elusive; before the seventeenth century, in fact, the rate of acquisition of new knowledge in this science was remarkably slow. Robert Lindsay cites the following, by way of explanation:

The basic theory of the origin, propagation and reception of sound was proposed at a very early stage in the development of human thought in substantially the form which we accept today: the ancient Greeks, according to the most reasonable interpretation of the records, evidently were aware that sound somehow rises from the motion of the parts of bodies, that it is transmitted by the air through some undefined motion of the latter and in this way 
ultimately striking the ear produces the sensation of hearing. Vague as these ideas were they were yet clarity itself compared with the ancient views on the motion of solid bodies as well as on light and on heat. The latter branches of physics had to go through a long course of development in which theory succeeded theory until the present stage was reached (Lindsay 1945: xi-xii).

The history of acoustics, then, primarily describes a process of refinement in experimental technique, which increasingly permitted more accurate recording of sound phenomena; it is not so much a history of theory, as it is a history of mechanics (see ibid.).

For the most part, discussions of acoustics prior to the seventeenth century were within the domain of speculative music theory; such names as Zarlino and Vincenzo Galilei figure prominently in the history of sixteenth-century acoustics.

It is, however, Galileo Galilei who is generally given credit for establishing a systematic phenomenological study of the science of sound (see Lindsay 1973:6). In 1638, Galileo published his Mathematical Discourses Concerning Two New Sciences. At the end of the discussion of the first day, Galileo introduces his ideas on acoustics, dealing especially with the concept of the frequency of vibrating strings. He writes:

I say, that 'tis neither the length, nor the tension, nor the thickness [of strings] that constitutes the nearest immediate Reason of the forms in musical intervals, but the proportion of the number of vibrations and percussions in the undulations of the air, striking the drum of our ear, which itself also doth tremulate under the same measures of time (quoted in Lindsay 1945:54).

Galileo was able to show that, although the ratio of lengths, thicknesses, or tension of vibrating strings was subject to variation for any given interval, the ratio of vibrations always remained the same. It should be pointed out that many of Galileo's ideas were not wholly original, and that he owed much to his father and other predecessors, as well as to his contemporaries, most notably Marin Mersenne.

Mersenne is normally credited with presenting the first comprehensive account of the vibration of strings, in his Harmonicorum Liber, which was published in Paris in 1636. 
One of Mersenne's more significant contributions to the field in this work was the measurement of the frequency of vibration of a long string (almost twenty feet in length). From the number of its vibrations he was able to infer the frequency of a shorter string of the same density and tension, which gave a musical note (see Lindsay 1945:xiii). ${ }^{4}$ Mersenne recognized that ". . other things being equal, the frequency of the vibration is inversely proportional to the length of the string, while it is directly proportional to the square root of the cross-sectional area" (quoted in Lindsay 1973:7).

Another acoustical question with which Mersenne concerned himself is the speed of sound in air. In ingenious experiments, involving the firing of canons and the recording of the time interval for the reception of the sound at predetermined fixed distances, Mersenne was able to arrive at the figure 1380 Paris feet per second, or about $450 \mathrm{~m} / \mathrm{sec}$ (see ibid.: 11). At $0^{\circ} \mathrm{C}$, sound actually travels at $331.7 \mathrm{~m} / \mathrm{sec}$ in air. When one considers the conditions under which Mersenne conducted his experiments, the discrepancy of his figure is remarkably small.

To Claude Perrault (1613-88) must go the honor of having published the first monograph dealing exclusively with acoustics (see Scherchen 1950:21). Volume II of Perrault's extensive Essais de physique ou Recueil de plusieurs traitez touchant les choses naturelles (Paris, 1680) is entitled "Du Bruit." That Perrault was breaking new ground with this publication is evidenced in his comments concerning "l'obscurité du sujet que je traite" (quoted in ibid.). Among other things, Perrault explores the acoustical properties of several musical instruments; he also presents a comprehensive survey of the reception of sound, which includes detailed diagrams of the organs of hearing. ${ }^{5}$

According to Scherchen, Perrault unfortunately was responsible for a misconception that remained current well into the eighteenth century: that sound is provoked not by vibration of a whole string, but by the molecular disturbance of its component parts (see Scherchen 1950:21). ${ }^{6}$ Nevertheless, his other observations concerning vibrating strings are surprisingly forward-looking. He writes that "even the simplest sound is really a collection of infinite bruits partiaux which combine to make one complete sound. Nonetheless, there is always one 
partial sound, stronger than the rest, which gives the total its particular character" (quoted in ibid.).

Two Englishmen, Robert Hooke (1635-1703), and Brook Taylor (1685-1731), named earlier as being influenced by Sauveur, also made significant contributions to the science of sound. Hooke discovered a plausible relationship between the frequency of vibration and pitch in an experiment that allowed a cog wheel to run against the edge of a piece of cardboard (see Lindsay 1973:7). Brook Taylor was the first to provide "a strictly dynamical solution of the vibrating string" (ibid.). From the equation of the curve of a string vibrating in what is now called its fundamental mode and the Newtonian equation of motion, ". . . he was able to derive a formula for the frequency of the fundamental vibration" (ibid.).

Sauveur accepted this body of knowledge from his predecessors and contemporaries, refined it, added to it, and transmitted it to subsequent eighteenth-century acousticians. His contributions to acoustics are preserved in six Mémoires presented to the Académie Royale des Sciences: "Sur la détermination d'un son fixe" (1700); "Système générale des intervalles des sons et son application à tous les systèmes et à tous les instruments de musique" (1701); "Application des sons harmoniques à la composition des jeux d'orgues" (1702); "Méthode générale pour former des systèmes temperées de musique, et de celui qu'on doit suivre" (1707); "Table générale des systèmes temperées de musique" (1711); and "Rapport des sons des cordes d'instruments de musique, aux flêches des cordes; et nouvelle détermination des sons fixes" (1713). In addition, Sauveur left unpublished an important manuscript entitled Traité de la théorie de la musique (Paris, Bibliothèque Nationale, fonds fr., n.a., 4674), which he completed in 1697. This latter work attempts to establish an acoustical basis for the composition of music.

Preserving the word "acoustics" for the study of sound was not Sauveur's only lasting contribution to the terminology in this science; he also was responsible for the following terms: "nodes" for those points on vibrating strings where no motion occurs; "loops" for the intermediate points on vibrating strings where very violent motion occurs; "fundamental" for the simple vibration (excluding the nodes) of a whole string; and "harmonic" for higher frequency vibrations (between nodal points) of parts of a vibrating string (see Lindsay 1945:xiv). 
We must also credit Sauveur with establishing an accurate method of determining the frequency of a given musical pitch. In the Mémoire of 1700 , he describes an ingenious method for determining the frequencies of two organ pipes, through the use of beats. The two pipes were tuned a semitone apart, in the ratio of 15:16. Lindsay explains:

By experiment he found that when sounded together the pipes gave six beats a second. By treating this number as the difference between the frequencies of the pipes the conclusion was that these latter numbers were 90 and 96 respectively [i.e., $15 \times 6: 16 \times 6$ ] (ibid.).

Sauveur most certainly was aware of the phenomenon of the harmonic series, and of its implications with respect to organ pipes and vibrating strings. Moreover, he noted that a vibrating string could produce the sounds corresponding to several of its harmonics simultaneously. As is the case with many of Sauveur's contributions, however, his presentation of this phenomenon is essentially descriptive. Dynamical and mathematical explanations of this and other phenomena had to wait for the next generation of acousticians (see ibid.: xv).

It is clear that the contemporaries of Loulie represented a group of individuals for whom the study of acoustics was new and exciting; and the seventeenth and eighteenth centuries were, indeed, extremely productive in the history of acoustics.

Loulié's discussions of various sound phenomena are neither as important, nor as influential as the work of the acousticians briefly described above. His presentation is primarily a descriptive one, and any mathematical calculations which he includes are quite simple. Nevertheless, Loulié demonstrates an understanding of many of the more forwardlooking discoveries that the work of his contemporaries had produced.

The organization of his essays is apparently random; the material in each of the sub-sections requires no prerequisite understanding of that contained within any of the other sections. Consequently, for present purposes, it has seemed appropriate to present Loulié's discussion of acoustics in a 
sequence somewhat different from that of the original, beginning with his general observations and proceeding to the more detailed descriptions of specific phenomena. ${ }^{7}$

In Ms. f. 156r Loulié initiates a discussion of sound by stating: "Sound, in general, is a particular type of movement, or trembling, or shaking of the smallest parts of a [sounding] body. This definition comprises sound in general; that is, all types of noise" (Ms. 6355, f. 156r) ${ }^{8}$ Like Sauveur, Loulié is approaching the study of sound as a general phenomenon, of which music is a particular type. It is clear that Loulie is particularly interested in the production of sound, and that its propagation and reception are of less importance. He subsequently describes several varieties of sound, accounting for their respective characteristics in terms of the movement which produces them (Ms. 63555, f. 156r; see also f. 147r). He states, for example, that a low sound results from slow vibrations (mouvements), and that a high sound results from rapid vibrations (Ms. 6355, f. 147r). Loulie maintains, moreover, that the amplitude of the sound produced is determined by the amount of air displaced through the molecular movement of sounding bodies (ibid.), ${ }^{9}$ and that the harshness or sweetness of a sound derives from inconsistencies in the surface of sounding bodies (ibid.). ${ }^{10}$

\section{Loulié continues:}

This trembling of the smallest parts is almost always joined by vibrations or shakings of larger parts in bodies which are capable of this; and it is in these vibrations that the lowness or height of sound is produced. There are sounds which are neither high nor low because there are no vibrations in the body which produces them. For example, if one strikes the inside of the hand with the end of a finger the sound which one hears is neither low nor high, but only strong or weak (Ms. 6355, f. 157r). ${ }^{11}$

Loulié makes two significant observations here: first of all, he notices that the propagation of sound depends upon the transmission of the vibration throughout a sonorous body. In other words, the sounding body, ideally, must be resonant. ${ }^{12}$ The major emphasis in this passage, however, is on the dependence of a musical tone on the reiteration of regular vibrations. Loulié explains: "Tone, taking this word for what there is of a 
fixed lowness or height in a sound, is an uninterrupted progression of several isochronous vibrations, that is, those [vibrations] which are made in equal amounts of time" (Ms. 6355 , f. $157 \mathrm{r}$ ) ${ }^{13} \mathrm{He}$ claims that without this progression of isochronous vibrations, even the finest ear is unable to determine relative pitch in a sound (ibid.). ${ }^{14}$

Like several of his contemporaries, for example Perrault and Sauveur, Loulié frequently draws analogies between the science of optics and that of sound. He writes:

When the vibrations are too' quick or when they are too slow, or when they are [of] unequal [number] or, finally, when the number of vibrations is too small, the ear is unable to judge the tone [i.e., the pitch] of the sound. Almost the same thing occurs with the eye which is unable to read a handwriting that is too tiny, or too large, or badly written, or if the writing is passed too quickly before the eyes, even though the handwriting is good (Ms. 6355, f. $157 \mathrm{v}) \cdot{ }^{15}$

Loulié classifies sound into three descriptive categories: physical sound, mathematical sound, and musical sound (Ms. 6355, f. 159v). Physical sound, he writes,

... is sound in general, or sound considered with respect to everything involved with its production, and [everything] which gives us the sensation [of hearing], as are all sounding bodies, air, the voice, the organs of hearing (ibid.). ${ }^{16}$

\section{Of mathematical sound Loulié states:}

Mathematical sound is sound which may be measured by the sizes of bodies in which the sound is produced, such as all strings or cylinders, and all other regular bodies, by whose relationships the ratios of their [resultant] sounds may be known (Ms. 6355, f. 160r). ${ }^{17}$

Loulié says of musical sound simply that it is measurable by the ear (ibid.).

Loulié also establishes three parameters by which to judge sound: its quality, its quantity, and its degree (Ms. 6355, f. 164v). He assigns each of these parameters a place of special 
importance within the three descriptive categories of sound defined above. He claims that observing the "quality" of sound, its production and reception, is the particular domain of physical sound. To mathematical sound belongs "quantity" that is, the various ways in which sound may be measured. Loulié ascribes "degree" to musical sound, insofar as the ear is able to judge the relative pitch of various sounds.

Before leaving Loulié's discussion of sound and its properties in general, it would be appropriate to present his brief discussions on the nature of vibrating strings. It is clear that much of his information on the subject comes from Mersenne. As noted above, however, Mersenne's Harmoniçorum Liber was one of the most comprehensive surveys of its time for the laws governing vibrating strings. Loulié writes that the number of vibrations of strings is inversely proportional to their lengths (Ms. 6355, f. 156r). Loulié was aware, moreover, that string length was not the sole determining factor of the frequency of vibrations in strings. He writes:

The less tension in a body, that is, the less compressed the parts, the slower are the vibrations and consequently the lower is the sound, and vice versa. Thus, the sound of a string stretched at a weight of two pounds is lower than the sound of the same string stretched at a weight of four pounds. The greater the volume of a body, the slower are the vibrations, and the lower is the sound (Ms. 6355, f. $159 \mathrm{r}) .{ }^{18}$

With these general acoustical principles established, it is now possible to move on to an investigation of Loulié's more detailed writings on acoustics.

Loulié's observations regarding musical intervals may be classified conveniently into two categories: intervals discussed with respect to their patterns of vibrations; and intervals derived mathematically through various divisions of the octave and its component parts. To the present writer's knowledge, approaching the subject of intervals from the point of view of their patterns of vibration is unknown before Loulié; it is, moreover, an ingenious and valid way of treating the topic.

Loulié begins with a few definitions. He describes an interval (accord) as ". . . the mixture of two notes. Consonance is the agreeable mixture of two notes. Dissonance is the 
disagreeable mixture of two notes" (Ms. 6355, f. 142r)..$^{19} \mathrm{He}$ expands these definitions as follows:

Accord or discord is the double impression made on the air by the vibrations of two sounding bodies. If these vibrations strike the air with a chute or cadence that the ear is able to sense, this is called an accord or a consonance. But if the air is struck in a manner such that the ear is not able to sense a cadence in the impressions, this is called a discord or dissonance (ibid.). ${ }^{20}$

With respect to these definitions, Loulié calls a cadence a series of vibrations (ibid.);21 it is, in other words, a succession of perceivable patterns of vibrations. With this in mind, Loulie is able to represent the vibration patterns of several intervals schematically, by drawing an analogy between these vibrations and rhythmic notation. A unison, for example, is represented as follows:

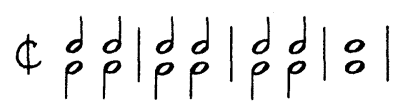

Loulié explains that ". . . in a unison, the air is always struck in the same manner" (Ms. 6355, f. 142r).22 "In an octave," Loulié writes, "the air is struck in the following way: one strong beat, one weak beat ..." (ibid.). ${ }^{23} \mathrm{He}$ represents the octave as:

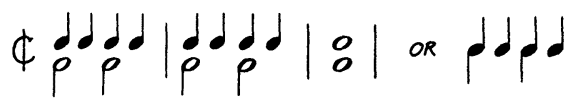

He claims that the second quarter note of each group, since it stands alone, is only half as strong as the first and third quarter notes; thus the second beats are often ignored, and one perceives a unison, rather than an octave.

Loulié next diagrams the vibrating pattern of the fifth:

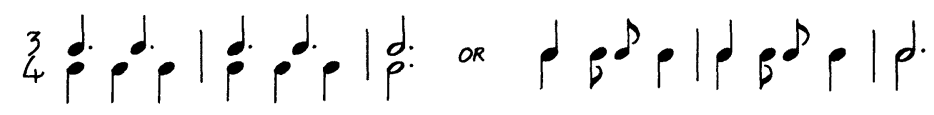

He explains:

In the fifth the air is struck four times [in each repeating pattern]. Although a coincidence of beats occurs only once in every four [of these strikings], the ear nevertheless, perceives a succession of only three beats, because the 
second and third, joined together, are isochronous with each of the other two, and the second of these smaller beats [i.e., the third of the four] is no more perceptible to the ear than was the second beat in the octave (Ms. 6355, f. 142v). ${ }^{24}$

The second and third beats in this pattern occur in the same amount of time as beat one, and as beat four; hence beats two and three are isochronous with one and four. It is unclear why Loulié should insist on the ear hearing this pattern as a succession of three, rather than four, beats. We may only assume that he, himself, perceived the interval of the fifth in this way.

The fourth is diagrammed as follows:

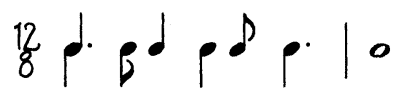

"The fourth, after the major third," writes Loulié, "has the most diversified pattern [of vibrations], but is in this respect a bit too much" (Ms. 6355, f. 145 r). ${ }^{25}$ He views this pattern, no doubt, as too complex for easy recognition. The major third is given the following pattern:

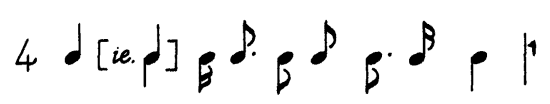

Of the major third Loulié writes: "The major third seems to me [to be] the richest and most agreeable of all the consonances" (Ms. 6355, f. 144r), ${ }^{26}$ citing as a reason, ". . . its batterie [i.e., the pattern of its vibrations] has more diversity than that of the other consonances" (ibid.). ${ }^{27}$ Although he claims he is unable to diagram the pattern of vibrations of the minor third (Ms. 6355, f. 143r), he provides the following:

$$
\rho \beta^{d} \beta^{d} p \cdot \rho p \rho
$$

Loulié claims that the minor third ". . . has a confused pattern of vibration because each pattern is divided into five, which is an unknown number in our mesures, outside of the fact that five is made up of three and two, which produce different values" (Ms. 6355, f. 145r). ${ }^{28} \mathrm{~A}$ minor sixth is given the pattern (Ms. 6355, f. 145v):

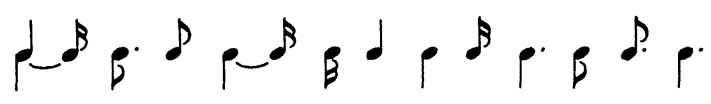


Loulié offers no explanation for the slurs in this scheme; it seems likely, however, that they indicate that the quarter notes to which the sixteenths are tied are to be considered doublydotted. The slurred sixteenth notes, in other words, do not represent beat articulations in this diagram. The major sixth is diagrammed as:

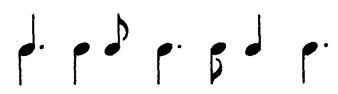

In addition to these, Loulié provides diagrams for several compound intervals (Ms. 6355, f. 142v-143r), including the twelfth:

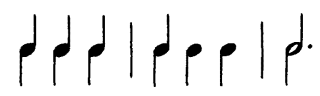

the tenth:

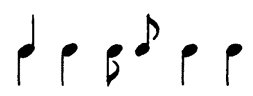

the fifteenth:

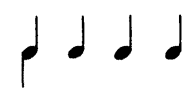

and the seventeenth:

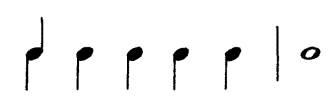

Presenting the vibration patterns of the various consonances according to a rhythmic scheme has at least two advantages. First of all, it accurately depicts the dimension of time in our perception of vibrations. But, perhaps more significantly, the diagrams of the various intervals remain valid whether one is describing vibrating strings, or cylinders, or whether one is considering either the length or the tension or the diameter of a vibrating string (see Lindsay 1945:xi-xii). How Loulié came across such a method of presentation is unclear; as mentioned above, the method seems not to have been used by any of his predecessors. It should also be pointed out that Loulié was not proposing a new way of representing musical intervals. He was, rather, more concerned with providing visual examples of his premise that a musical interval is the combination of the vibrating patterns of two separate sounds. 
Loulié's second method of dealing with musical intervals is a more traditional one: the mathematical derivation of the various divisions of the octave. The ratios which Loulie derives in this process, however, are still relationships of vibrations, and not of string lengths or of some other variable. In this respect, then, this portion of his acoustical writings is current.

Loulie describes two varieties of ratios. The first is simple, in which ". . . the difference of one of the terms is of a single part of a larger term, such as $1 / 2$ or $2 / 3$ " (Ms. 6355, f. 149r). ${ }^{29}$ These are, in fact, superparticular ratios, of the class $\frac{n+1}{n}$. The composite, or complex ratios are all those other than the superparticular ones.

Before presenting his calculations for the derivation of the interval ratios, Loulié sets down some premises. The first is that the larger the numbers in the terms of superparticular ratios, the smaller will be the interval. Thus $1 / 2$ describes a larger interval than does $2 / 3$. It follows axiomatically that ". . . the largest of all the simple ratios is $1 / 2 . . . "($ Ms. 6355, f. $149 \mathrm{v}) .^{30}$ The octave then, is the largest of the simple intervals of music. Loulié writes:

Practice, experience, [and] custom teach that the largest simple musical interval divides itself into seven smaller intervals. Thus eight terms are required, of which 1 is the first and 2 is the eighth. It is because of this that one calls it the octave (ibid.). ${ }^{31}$

He claims, further, that intervals such as $2 / 3,3 / 4$, and $4 / 5$, of which the octave is composed, must themselves be divided until eight terms have been derived from 1 to 2 (Ms. 6355, f. 150r).

Loulié describes the process for the derivation of the intervals as subtraction or division:

One can discover by reasoning and by calculation all the musical intervals which are in use, and even more than these, first by dividing the larger ones into two smaller ones, by the arithmetic mean (Ms. 6355, f. 166r). ${ }^{32}$

An octave, for example, divides itself into two intervals, through the determination of the arithmetic mean of the two terms of its ratio, 1:2. The two terms are doubled, and their sum is divided by two; hence, $1: 2$ divides into $2: 3: 4$, or $2: 3$ and $3: 4$ (ibid.). Similarly, 2:3 divides into $4: 5$ and 5:6; 4:5 divides 
into $8: 9$ and $9: 10 ; 8: 9$ divides into $16: 17$ and $17: 18$; and $17: 18$ divides into $32: 33$ and 33:34. Loulié cautions:

I could continue this division further without knowing at which one to stop, unless the ear and voice were consulted; that is, unless these intervals were put into practice ... (ibid.). ${ }^{33}$

By this method, Loulie arrives at an octave of the following composition (Ms. 6355, f. 150r):

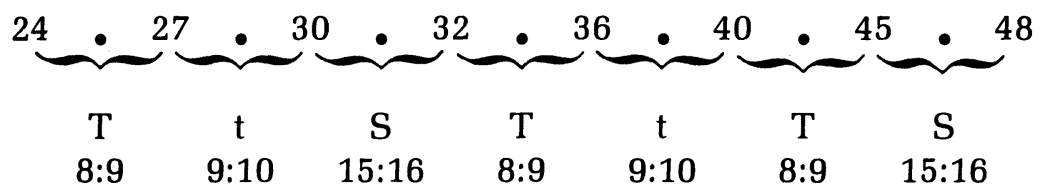

It can be seen that between the first and second, the fourth and fifth, and the sixth and seventh terms is the interval of the major whole tone $(8: 9)$. Between the second and third and the fifth and sixth terms, however, is a minor whole tone $19: 10)$. This, of course, results in an inconsistency in the structure of the tetrachords which are included in the first four terms $\mathrm{T} t \mathrm{~S}-$ and the last four terms - $\mathrm{t} \mathrm{T} \mathrm{S}$. Although such an arrangement is in agreement with Zarlino (1573:151), it is in opposition to the standard seventeenth-century French view, which held that the first two terms of an octave, from ut to re, was a minor tone of 9:10 (see Descartes 1668:80-81). From re to $\mathrm{mi}$, on the other hand, was normally counted as a major whole tone in French sources (ibid.). In fact, Loulié himself follows the standard French approach in his Éléments ou principes de musique, where the following chart appears (Loulié 1696:47):
Ut à Re comme 10 à 9
Re à Mi comme 9 à 8
$\mathrm{Mi}$ à $\mathrm{Fa}$ comme 16 à 15
Fa à Sol comme 9 à 8
Sol à La comme 10 à 9
La à $\mathrm{Si}$ comme 9 à 8
Si à Ut comme 16 à 15

In such an arrangement the tetrachord, ut-fa, has the same 
configuration as the tetrachord, sol-ut. By placing the major whole tone below the minor whole tone in Ms. 6355, however, Loulié achieves a consistent arithmetic division in the derivation of his intervals: the major third (4:5) divides into 8:9 and $9: 10$ just as the fifth $(2: 3)$ divided into $4: 5$ and $5: 6$, and the octave divided into $2: 3$ and 3:4. It should be mentioned that as late as 1722, Rameau was to adopt the older French distribution of major and minor whole tones in his Traité de l'harmonie (see Rameau 1971:28).

Loulie categorizes the two resultant intervals in the division of a ratio by its arithmetic mean as either direct or complementary. He explains:

The intervals or simple ratios which are [measured] from the first term to any of the other terms are called direct intervals. The other simple intervals which are [measured] between the other terms are called complementary intervals. Thus, $2: 3$ is direct, but $3: 4$ is complementary (Ms. 6355, f. 167r). ${ }^{34}$

He gives the following table (Ms. 6355, f. 167v):

\begin{tabular}{|cc|rr|rr|} 
Intervalles directs & \multicolumn{2}{|c|}{$\begin{array}{c}\text { Intervalles de } \\
\text { Complement }\end{array}$} & $\begin{array}{c}\text { Differences des } \\
\text { Complements aux } \\
\text { Directs }\end{array}$ \\
1 & 2 & & & \\
2 & 3 & 3 & 4 & 8 & 9 \\
4 & 5 & 5 & 6 & 24 & 25 \\
8 & 9 & 9 & 10 & 80 & 81 \\
\hline
\end{tabular}

It can be seen that Loulié classifies the octave, fifth, major third, and major whole tone as direct, while he characterizes the fourth, minor third, and minor whole tone as complementary.

In sum, two items in Loulié's discussion of musical intervals are especially noteworthy. First is his novel approach to the presentation of intervals through their schematic representation in rhythmic notation. The second is his insistence on the use of ratios of vibrations, rather than the ratios of string lengths, in his derivation of the intervals through the division of the octave.

In his introduction to his observations concerning musical intervals, Loulié claims that there are at least five causes for the pleasure which the accords may give us: 
1st from the equality with which the strokes of the vibrations are given.

2nd [from] the frequent union [i.e., synchronization] of the vibrations.

3rd [from] the pattern in which the strokes are given which one might call the rhythmic pattern.

4th [from] the diversity in these sequences or patterns. 5 th [from] the idea or shadow of the equal consonances which give the impression of the first [vibrations] vibrations which have occurred [are joined together] with vibrations which are [actually] occurring, which one calls accord de resonnance (Ms. 6355, f. 143r). ${ }^{35}$

Louliê's accord de resonnance is a difficult phenomenon to describe, since it encompasses a number of concepts. Not only is it the quality which transforms noise in general to measurable musical sound, it is also, according to Loulié, the quality which engenders a rich array of overtones ${ }^{36}$ in certain intervals. Loulié initiates his discussion of resonance with the following:

The slowest vibrations of a sounding body are so quick that the impression of the first is conserved in the ear through the 2nd, 3rd, 4th, and 5th, and by this in such a way that the idea of the first vibration which has just occurred, joined with the impression of the second vibration, produces the sensation of the octave, because in the first stroke the ear is struck less forcefully than in the second, which is the beating pattern of the octave, to make one strong stroke and one weak stroke, in equal amounts of time. The idea of the 1st and of the 2nd vibrations, joined with the third which is [actually] occurring, produces the sensation of the 12th, because in the 1st and in the 2nd strokes the ear is struck less forcefully than in the 3rd; and this is the beating pattern of the 12th, which consists of a weak stroke, a weak stroke, and a strong stroke in equal amounts of time. The idea of the 1st, 2nd, and 3rd vibrations, joined with the 4 th vibration, produces the sensation of the 15th, which consists of three weak strokes and one strong stroke, in equal amounts of time. The idea of the 1st, 2nd, 3 rd, and 4 th vibrations, joined with the 5 th, produces the sensation of the 17 th, because the 17th consists of 4 weak strokes and a 5th strong one (Ms. 6355, f. 144r-144v). ${ }^{37}$

It is clear that Loulié views resonance as much a function of the process of hearing and perception as a physical pheno- 
menon. The passage just cited, moreover, is certainly a rationale for the existence of harmonics; but they are described with respect of sound vibrations. In fact, it is probably one of the earliest discussions of partial tones, or harmonics, where the point of reference is not a vibrating string. ${ }^{38}$ Speaking specifically of the vibration pattern of a musical sound, Loulie is able to conclude: "This is the reason why in a single low note, such as the sound of the larger clocks or strings, one hears the $8 \mathrm{ve}$, the 12 th, the 15 th, and the 17th, etc." (Ms. 6355, f. 144v). ${ }^{39}$

It would, indeed, be interesting to know how far Loulie extended the perceptible range of harmonics, ${ }^{40}$ for in his subsequent discussion of resonance, he is only concerned with the first five partial tones and how these relate to the combination of more than one fundamental note. He writes: "These accords de resonnance are perfectly in tune with the upper note in a major third, for the 8ve makes a minor 6th, the 12 th makes a minor tenth, the 15 th makes a [13th], [and] the 17 th makes a double octave" (MS. 6355, f. 144v).41

The reader is referred to Example 1, below, for an explanation of this passage:

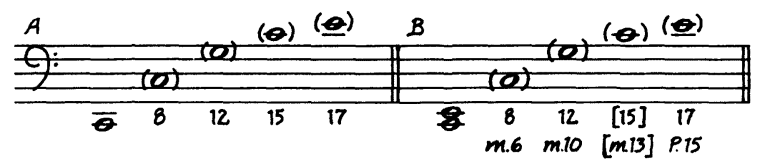

Example 1. Loulié's accords de resonnance

Example 1a represents the first five partial tones of a fundamental on $\mathrm{C}$, in which the harmonics are placed in brackets. Example 1b shows the same arrangement, only with an added $\mathrm{E}$ to the fundamental. Loulié claims that the accords de resonnance tune themselves well with the interval of a major third, since they form such consonances as sixths, tenths, and double octaves with it. ${ }^{42}$ Loulié fails to point out that the subsequent higher harmonics of the fundamental $\mathrm{C}$ are at least potentially dissonant with the note $\mathrm{E}$ (and, indeed, with the fundamental itself).

It is Louliés contention, however, that the partial tones of a fundamental are not perceived as actual intervals above the fundamental. After presenting the term accord de fourniture as synonymous with accord de resonnance, Loulié states: 
An accord de fourniture is that [which is derived] from the lower sound which is the only sound one counts in the harmony, and not the higher sound; this higher sound is ordinarily so weak in these accords that it is as if confused with the lower sound which is much stronger; and the higher sound of this accord simply engenders a change in the quality of the lower sound, giving it something of a piquant [quality], and the ear, which hardly perceives it, confuses it with the lower sound (Ms. 6355, f. 145v).43

As proof of the fact that the accords de fourniture or de resonnance do not enter into our perception of a harmony, Loulie cites the example of organ ranks which combine a major third as part of the fundamental note. One is often required to play a minor third above the bass on this rank; Loulié notes that this would result in an insufferable dissonance if we were to hear the component major third as an actual interval (Ms. 6355, f. 146r).

Willi Apel defines resonance as "... the transmission of vibrations from a vibrating body to another body. This phenomenon takes place only when the two bodies are capable of vibrating at the same frequency (or a harmonic thereof)" (Apel 1969:726). We may conclude that Loulié's concept of accord de resonnance is considerably removed from what was to become a standard definition of the term. Resonance, for Loulie, is the simultaneous sounding of several harmonics with a fundamental tone, such that the quality of the sound of the fundamental is enhanced. The description of this phenomenon in terms of the perception of sound vibrations is most noteworthy.

The final two items which Loulié treats in his essays on sound are closely related: beats and tuning. In the case of the former, Loulié shows a surprisingly sophisticated understanding of the phenomenon of beating. Counting beats in the process of tuning musical instruments, of course, was well-established by Loulié's time; nevertheless, Loulié shows insight into the phenomenon outside its practical application to tuning. Loulié writes:

Notes which are perfectly in tune at the unison, at the $8 \mathrm{ve}$, at the $5 \mathrm{th}$, at the $4 \mathrm{th}$, at the major $3 \mathrm{rd}$, and at their compounds, combine so well that the ear senses no shakings. But when two notes are not precisely at the unison, at the $8 \mathrm{ve}$, at the 5 th, at the 4 th, or at the major 
$3 r d$, or when they create a dissonance if sounded together in such a way that the ear hears them together, the ear senses a beating which is just as violent or sudden as the two notes are distant from a consonance, and which slows down gradually as the two notes approach a consonance (Ms. 6355, f. 152r). ${ }^{44}$

Loulié does not make it clear whether the consonances described in the above passage are restricted to the unison, octave, fifth, fourth, and major third (i.e., those he specifies in the passage), or whether he would also include the minor third and the major and minor sixths. ${ }^{45}$ In fact, Loulié should not restrict the phenomenon of beating to intervals approaching a consonance at all, for beating will occur at the approach of any just, or pure interval.

Nevertheless, Loulié cites the following example:

Let us suppose that in one second a string makes one hundred vibrations, and that another in the same second makes one hundred and one; these [vibrations] are capable of striking the air together only after the first has struck a hundred times, and the second has struck one hundred and one times; now the air [is at these times] being pushed or struck once again more strongly since it is receiving a double impression, for all the other strokes are given one after the other, and might thus be said to be false. The ear which receives one beat once again more strongly, perceives it thus, and it is in this that exists what musicians call beats. And this may occur either from second to second, or from half second to half second, according to the ratios of the strings (Ms. 6355, f. 154v). ${ }^{46}$

The example Loulié has presented here accounts for the phenomenon of beating only when the frequencies of vibrations between the two strings have a difference of one, for "... the number of beats per second is equal to the difference in the frequencies of the two primary sounds" (quoted in Culver 1947:19). ${ }^{47}$ It also leaves unexplained Loulié's claim that beating occurs only as consonances are approached.

Loulié explains beating by comparing the frequencies of two sounds which are each tuned hypothetically at 100 vibrations per second. "If they are put in the ratio of 100 to 99," he notes, "the beating will be very slow" (Ms. 6355, f. 152r). ${ }^{48}$ The 
process of systematically lowering the frequency of one of the sounds is continued to 100 to 50 (the ratio of the octave); the ratios of 100 to 96 , or 25 to 24 , and 100 to 90 , or 10 to 9 , are described as demonstrating beating which is "very quick" (Ms. 6355, f. 152r-152v). ${ }^{49}$ Loulié concludes:

It would seem that 100 to 90 would be the greatest dissonance, for the term 90 is equi-distant from the two terms of the nearest consonance, 100 [and] 80 , and these tune themselves perfectly as experience [teaches us] (Ms. 6355, f. 153v). ${ }^{50}$

Besides their obvious usefulness in tuning musical instruments, Loulié offers yet another ingenious application of beats to the study of sound. He writes:

One would not know how to count the slowest vibrations of a single sounding body, because the slowest ones which the ear is able to perceive are too quick to be able to be counted. But one may count them by way of beats which the ear perceives when the vibrations are in dissonance ... (Ms. 6355 , f. $162 v) .51$

Loulié's method, of course, is the very one Sauveur employed in fixing the pitch of organ pipes. Loulie acknowledges the latter's endeavors in this area, stating that "Monsieur Sauveur is working at finding a fixed pitch and it seems he will discover it and that he will fix it through the use of beats" (Ms. 6355, f. $163 \mathrm{v}) .{ }^{52}$ It is difficult to determine whether Loulié's concept for the use of beats anticipated Sauveur's Mémoire of 1700 or not. It is clear, at any rate, that Loulié was well versed in this rather new approach to the practical applications of the phenomenon of beating.

Loulié's discussion of tuning is almost completely practical in content; the few paragraphs which he devotes to the subject are concerned mainly with the process of putting one sound in unison (or at the octave) of another. There is no large-scale tuning system described, such as in his published Nouveau Sistème of 1698. As shall become apparent in what follows, however, we may infer Louliés preference for a one-fifth comma meantone system.

There are, according to Loulié, two methods for putting one string at the unison or the octave of another: 
The first is accomplished at the cessation of undulations or beats which the notes of two strings that are not completely in unison or at the octave produce (Ms. 6355, f. $154 \mathrm{v}) \cdot{ }^{53}$

Loulié continues by describing the same phenomenon of beating which was observed above. He writes:

It is by having these beats cease that one may put one string at the unison of another, which is accomplished by raising it or lowering it until the beating stops (Ms. 6355, f. 155r). ${ }^{54}$

He subsequently states:

What I have just said of the unison must also apply to the octave, the fifth, the fourth, and the major 3rd, the maintained proportions of which produce no beatings when they are perfectly in tune (ibid.). ${ }^{55}$

It is not only in the cessation of beats that the phenomenon of beating may be applied to tuning. Loulié also uses beats to change a just fifth into a tempered fifth. A just fifth is one in which "... the two notes ... unite so well that the finest ear senses no beating or shaking," and which "... is in the ratio of 3 to 2" (Ms. 6355, f. 154r). ${ }^{56}$ The tempered fifth ". . . is a just 5 th from which is subtracted $1 / 5$ of the ratio 81 to 80 , or else... a just 5 th from which is removed $1 / 405$ " (ibid.). ${ }^{57}$ Loulié notes:

Although the tempered fifth is defective and does not have as much sweetness as the just fifth, nevertheless, the ear is not at all offended by it, and it has the advantage over the just fifth in being able to enter into the harmony of all sorts of music, whereas the just fifth is only able to enter into the harmony of the drones on a vielle or a musette, or in that rank of an organ called furniture stop, or at most in certain trumpet airs (Ms. 6355, f. 154r-154v).58

From the passages cited above it is clear that Loulié is adopting a one-fifth comma temperament, which compromises the purity of the fifths so that the thirds may remain just. It will be recalled that Loulié's published Nouveau Sistème espoused a one-quarter comma meantone tuning system. The one-fifth comma system allows for greater versatility for use in extreme 
keys (i.e., those with more than three flats or three sharps in the signature) (see Barbour 1955:35-36).

Loulie claims that the method of tuning by the use of beats is the most common and efficient one (Ms. 6355, f. 155r). But there are certain occasions when its application is not possible: when the tuner is not able to perceive beats; or when a string vibrates with beats by itself (i.e., if there is interference, such as with a "wolf") (ibid.). In these situations one must resort to what Loulié calls "tuning by the tone of the string" (ibid.).59 The latter method is merely a matter of matching pitches, so that, to the ear's judgment, the two strings are at a unison. (Ms. 6355, f. 155v).60

Loulié demonstrates a remarkable familiarity with several acoustical phenomena, including sound production and reception, harmonics or partial tones, and beats. That he was aware of the newer discoveries in this field is to his credit; that he was able to apply these discoveries to his own understanding of the nature of sound, and to coordinate these in easily understood essays, is a tribute to his abilities as a teacher of music theory. 


\section{NOTES}

1. For a more thorough examination of the contents of Ms. 6355, see Semmens 1980.

2. "J'ay donc crû qu'il y avoit une science supérieure à la musique, que j'ay appellée Accoustique, qui a pour objet le Son en général, au lieu que la Musique a pour objet le Son entant qu'il est agréable à l'oüie. Pour traiter cette science à la manière des autres, \& surtout de l'Optique, avec laquelle elle a beaucoup de raport, il auroit fallu expliquer la nature du Son, l'organe de l'oüie, $\&$ en détail toutes les proprietez du Son, pour en conclure les causes de l'agrément \& du desagrément des Sons qui servent d'objet de la Musique \& à la sympathie des Sons; \& enfin les machines non seulement de la Musique en particulier, mais encore de l'Accoustique en général." Translation by Maxham 1976: II, 1-2. Note: In most respects, the original orthography of seventeenthand eighteenth-century sources has been retained throughout this study.

3. For a comprehensive survey of the development of the science of acoustics, see Lindsay 1973.

4. This was apparently the first direct determination of the frequency of a musical sound.

5. Perrault was primarily a physiologist, whose skill is well-represented in his Mécanique des animaux (Paris, 1680).

6. As an example of the acceptance of this theory, see De la Hire 1736.

7. Representative items have been selected for analysis below.

8. "Le son en général est une espèce particulier de mouvement, ou tremoussement, ou fremissement de plus petittes parties d'un corps. Cette definition comprend le son en général. C'est à dire touttes sortes de bruit."

9. "Le son gros, grand, Epais, massif ... consiste dans un plus grand quantité d'Air battu. Le son petit, menu, mince ... consiste dans une petitte quantité d'Air battu." so[ nores ]."

10. "Aspre [ou] aigre vient de l'inégalité de la surface des corps

11. "Ce tremblement des plus petittes parties est presque toujours joint aux vibrations ou secousses des parties grossières, dans les corps qui en sont capables; et c'est dans ces vibrations que consiste le Grave, ou l'Aigu du son. Il y a des sons qui ne sont ny graves ny aigus, parce qu'il ne se trouve aucune vibration dans les corps qui les produissent; par ex. si l'on frap le dedans de la main avec le bout du doigt le bruit que l'on entend n'est ny grave ny aigu, mais seulement fort ou foible."

12. Loulié does not use the word "resonance" in this context, but rather in a specialized discussion of harmonics.

13. "Ton en prenant ce mot pour ce qu'il y a dans le son de grave ou d'aigu determiné, est une suite non interrompue de plusieurs vibrations issocrones, c'est à dire ceux qui se font dans des Temps égaux."

14. "Sans cette suite de plusieurs vibrations issocrones, l'oreille la plus fine ne peut pas determiner à quel ton est un son ..."

15. "Quand les vibrations sont trop presses, ou quand elles sont trop lentes, ou quand elles sont inégalles, ou enfin quand le nombre des vibrations est trop petit, l'oreille ne peut pas juger du ton du son. La même chose arrive à peu près à l'oeil qui ne peut pas biens lire une écriture dont les caractères sont trop menus, ou trop gros ou mal formez, où lorsqu'on passe trop viste devant les yeux l'écriture quoyque les caractères soient bien formez." 
16. “. . . est le son en général ou le son consideré par rapport à tout ce qui sert à sa production et à nous en donner le sentiment comme sont tous les corps sonores, l'air, la voix, les organes de l'ouye."

17. "Son mathématique est le son qui peut être mesurer par les grandeurs des corps dans qui le son est produit comme sont touttes les cordes ou cilindres et tous les autres corps reguliers par le rapport desquels on peut connoitre le rapport de leurs sons."

18. "Moins un corps est tendu, c'est à dire moins les parties ont de roideur, plus les vibrations sont lentes et le son par conséquent plus grave et au contraire. Ainsi le son d'une corde tendue par le poids de deux livres est plus grave que le son de la même corde tendue par le poids de quatre livres. Plus le corps a de volume et plus les vibrations sont lentes et le son plus grave."

19. ". . . le meslange de deux sons. Consonance est le meslange agréable de deux sons. Dissonance est le meslange desagréable de deux sons."

20. "Accord ou discord est la double impression qui font sur l'air les vibrations de deux corps sonores. Si ces vibrations frappent l'air avec une chute ou cadence qui puisse sentir l'oreille cela s'appelle accord ou consonance. Mais si l'air est frappé au manière que l'oreille ne puisse pas sentir de cadence dans les coups cela s'appelle discord ou dissonance."

21. "Le cadence des vibrations est une batterie."

22. "Dans l'unisson l'air est frappé toujours de la même manière."

23. "Dans l'octave l'air est frappé de la manière suivante, sçavoir un coup fort, un coup foible ..."

24. "Dans la quinte l'air est frappé quatre fois. Quoy que l'union des coups ne se fasse que de quatre en quatre l'oreille cependant ne fasse qu'une batterie de trois coups parce que le $2 e$ et le troisieme joints ensemble sont issocrones à chacun des deux autre[s] et le $2 e$ de ces deux petits coups n'est pas plus apercu de l'oreille, que le 2e coup dans l'8e."

25. "La quarte après la tierce majeure a la batterie plus diversifiée mais elle l'est un peu trop."

26. "La tierce majeure me semble la plus riche et la plus agréable de touttes les consonnances."

27. "Sa batterie est plus diversifiée que celle des autres consonnances."

28. "La $3 \mathrm{~min}$ a la batterie confuse parce que chaque coup est divisé en cinq, qui est un nombre inconnu dans nos mesures outre que 5 est composé de 3 et de 2 qui donne de differents valleurs ..." It was, of course, the minor third which was to give Rameau so much trouble in his derivation of intervals in the Traité de l'harmonie (Paris, 1722). See Rameau 1971: xxii.

29. ". . . la difference d'un des termes est d'un seul partie de plus grande comme de moitié, d'un tiers."

30. "Le plus grand de tous les rapports simples est $1 / 2 \ldots$.

31. "La pratique, l'expérience, l'usage apprennent que l'intervalle simple de musique le plus grand se divise en sept plus petits intervalles. Ainsi il faut huit termes dont 1 est le premier et 2 est le huitiesme. C'est à cause de cela qu'on l'appelle l'octave."

32. "On peut trouver par le raisonnement et par le calcul tous les intervalles de musique qui sont en pratique et même au de là. 1er en divisant les plus grands en deux plus petits, par le milieu arithmetique."

33. "Je pourrois pousser la division plus loin sans sçavoir à laquelle m'arrêter à moins de consulter l'oreille et la voix, c'est à dire à moins de mettre ces intervalles en pratique..." 
34. "Les intervalles ou raisons simples qui sont du 1er terme à chacun des autres termes s'appellent intervalles directs, les autres intervalles simples qui sont entre les autres terms s'appellent intervalles complements; ainsi 23 est direct, mais 34 est de complement."

35. "1er De l'egalité avec laquelle se donnent les coups des vibrations. 2e L'union fréquente des vibrations.

3e La cadence avec laquelle les coups se donnent qu'on peut appeller le rhythme batterie.

4e La diversité de ces chutes ou batteries.

5e L'idée ou ombre des consonnances d'Egalité qui fait l'impression des premières - vibrations qui ont passé avec vibrations qui passe[nt] qu'on appelle - accord de resonnance."

36. Although Loulié uses neither the term "overtones" nor Perrault's and Sauveur's bruits partiaux or harmoniques, it is clear that this was one of the phenomena he had in mind in his discussion of resonance.

37. "Les vibrations les plus lentes d'un corps sonores sont si prestes que l'impression de la première se conserve dans l'oreille jusqu'à la $2 \mathrm{e} 3 \mathrm{e} 4 \mathrm{e}$ et $5 \mathrm{e}$ par de la de sorte que l'idée de la première vibrat ${ }^{n}$ qui vient de passer jointe à l'impression de la $2 e$ vibration fait sentir l'octave parce que dans le premier coup l'oreille est frappé moins fort que dans le 2e, qui est la batterie de l'octave de faire un coup foible et un coup fort avec égalité. L'idée de la première et de la $2 \mathrm{e}$ vibrat ${ }^{\mathrm{n}}$ jointes à la $3 e$ qui passe, fait sentir la 12e parce que dans le le[r] et dans le $2 e$ coup l'oreille est frappé moins fort que dans le 3e et c'est la batterie de la 12e qui consiste dans un coup foible un coup foible et un coup fort avec égalité. L'idée de la $1 \mathrm{e} 2 \mathrm{e}$ et $3 \mathrm{e}$ vibrat ${ }^{\text {ns }}$ jointes à la $4 \mathrm{e}$ vibrat ${ }^{\mathrm{n}}$ fait sentir la $15 \mathrm{e}$ qui consiste dans trois coups foibles et un coup fort avec égalité. L'idée de la 1.2. 3. et 4 vibrations jointes à la 5 fait sentir la 17 parce que la 17 consiste dans 4 coups foibles et la 5e fort."

38. John Wallis is normally given credit for discovering harmonics, and the vibration of strings in aliquot parts, in his "On the Trembling of Consonant Strings, a New Musical Discovery" of 1673. See Lloyd 1954. Sauveur, in his Mémoires of 1701 and 1702, also observes the phenomenon from the point of view of vibrating strings. In the 1702 Mémoire, "Application des sons harmoniques à la composition des jeux d'orgues," the principle of harmonics is derived from the properties of vibrating strings is transferred to the tuning and combination of organ pipes. Perrault's discussion of bruits partiaux is also with respect to vibrating strings.

39. "C'est la raison pourquoy dans un seul son grave comme est le son des plus grosses cloches ou cordes on entend l'8ve la $12 \mathrm{e}$ la 15 et la $17 \mathrm{e}$ etc."

40. Sauveur extended this to the thirty-second harmonic. See Maxham 1976:I, 100.

41. "Ces accords de resonnance s'accordent parfaitement avec le son aigu de la tierce majeur, car l'8ve fait la $6 e \mathrm{~min}$ la $12 \mathrm{e}$ fait la $10 \mathrm{e}$ min la 15 fait la [13e] la 17 fait la double octave."

42. It is, no doubt, the compatibility of the major third with the harmonics of the bass note of this interval which renders it, according to Loulié, so rich in resonance. See Ms. 6355, f. 145v. 
43. "Accord de fourniture est celuy au son duquel on a seulem' égard dans l'harmonie, et non au son aigu; lequel son aigu est ordinairement si foible dans ces accords qu'il est comme confondu avec le son grave qui est beaucoup plus fort, et le son aigu de cet accord ne fait simplement que changer la qualité du son grave en luy donnant quelque chose de plus piquant et l'oreille qui l'apperçoit à peine le confond avec le son le plus bas."

44. "Les sons qui sont parfaite ${ }^{\mathrm{mt}}$ d'accord à l'unisson, à l'8e à la 5 . à la 4. à la 3 maj et à leurs repliques s'unissent si bien que l'oreille ne sent aucunes secousses. Mais lorsque deux sons ne sont pas précisem' à l'unisson, à l' $8 e$ à la 5 ou à la 4 ou à la 3 maj ou qu'ils sont en dissonance si l'on les sonne ensemble en sorte qu'une même oreille les puisse entendre ensemble, l'oreille sent un battement qui est d'autant plus violent ou plus subit que les deux sons sont plus esloignez de la consonance, et qui se rallentissent à mesure que ces deux sons approchent de la consonnance."

45. Throughout Ms. 6355, Loulié describes the consonances as the thirds, sixths, the fifth, and the octave (note, not the fourth); see, for example, f. 169r.

46. "Supposons que dans une seconde de minutte une corde fasse cent vibrations et qu'une autre dans la même seconde fasse cent un, elles ne doivent frapper l'air ensemble qu'après que la 1er a frappé cent fois, et que la 2e a frappé cent fois, alors l'air étant poussé ou frappé une fois plus fort puisqu'il reçoit une double impression, car tous les autres coups sont donnez l'un après l'autre et pour ainsi dire a fausse, l'oreille qui reçoit un coup une fois plus fort s'en aperçoit ainsi et c'est en cela que consiste ce que les musiciens appellent battements. Et cela peut arriver ou de seconde en seconde ou de demie seconde en demie seconde, selon les differents rapports des cordes."

47. Sauveur stated this law in his Mémoire of 1700.

48. "Si on les met en raison de 100 à 99 le battement sera très lent." 49. “. . . très prompt."

50. "Il paroit que 100 à 90 doit être la plus grande dissonance parce que le terme 90 est égallement esloigné des deux termes de la plus prochaine consonnance 100.80 et cela s'accorde parfaitem' avec l'expérience."

51. "On ne scauroit compter les vibrations les plus lentes d'un seul corps sonores, parce que les plus lentes que l'oreille puisse sentir sont trop viste pour pouvoir être compter. Mais on les peut compter par le moyen des battements que l'oreille sent lorsque les vibrations sont en dissonances ..."

52. "Monsieur Sauveur travaille à trouver le son fixe et il y a apparence qu'il le trouvera et qu'il le fixera par le moyen des battements."

53. "Le 1er se fait par la cessation des ondulations ou battements que produisent les sons de deux cordes qui ne sont pas tout à fait à l'unisson ou à l'octave."

54. "C'est en faisant cesser ces battements qu'on peut mettre une corde à l'unisson d'une autre, ce qui se fait en la montant ou la baissant jusqu'à ce que ces battements cesse[nt]."

55. "Ce que je viens de dire de l'unisson se doit entendre de l'octave, de la quinte, de la quarte et de la $3 e$ maj la proportion gardée desquels ne font sentir aucun battement lorsqu'ils sont dans une justesse parfaite."

56. ". . . les deux sons ... s'unissent si bien que l'oreille la plus fine ne sent aucun battement ou secousses;" "... est en raison de 3 à 2."

57. ". . . est la quinte juste dont on a retranché $1 / 5$ de la raison 81 à 80 , ou bien ... la quinte juste dont on a osté 1/405." 
58. "Quoy que la quinte temperée soit defectueuse et qu'elle n'ait pas tant de douceur que la quinte juste, neantmoins l'oreille n'en est nullem' choquée, et elle a l'avantage par dessus la quinte juste de pouvoir entrer dans l'harmonie de toutes sortes de musique, au bien que la quinte juste ne scauroit entrer que dans l'harmonie du bourdons de vielle et de musette, ou dans le jeux d'orgue qu'on appelle de fourniture, ou bien au plus dans de certains airs de trompette." 59. ". . . accorder par le ton de la corde."

60. Loulié does not indicate whether tuning "by tone" is also applicable to intervals other than the unison. 


\section{REFERENCES}

APEL, W.

1969: "Resonance," in Harvard Dictionary of Music. 2nd edition. Cambridge, Mass.: Harvard University Press, 726.

BARBOUR, J. M.

1955: Tuning and Temperment. East Lansing: Michigan State University Press.

CULVER, C.A.

1947: Musical Acoustics. 2nd edition. Philadelphia: The Blakiston Company.

D'ALEMBERT, J.

1747: "Recherches sur la courbe que forme une corde tendue mise en vibration," Historical Academy of Science (Berlin), III, 214-19.

DE LA HIRE, P.

1730: "Explication des différences des sons de la corde tendue sur la trompette marine," Mémoires de l'Académie Royale des Sciences, Année 1692. Paris: Archives de l'Académie des Sciences, IX, 330-50.

1736: "Expériences sur le son," Mémoires de l'Académie Royale des Sciences, Année 1716. Paris: Archives de l'Académie des Sciences, XXXV, fol. 311v-312v; 321-323v.

DESCARTES, R.

1668: Compendium musicae (ca. 1618). Translated by Nicolas EULER, L. Poisson. Paris: Charles Angot.

1727: Dissertatio physica de sono. Basel: E. \& J. R. Thurnisiorum. GALILEI, G.

1730: Mathematical Discourses Concerning Two New Sciences. Translated by Thomas Weston. London: J. Weston.

LAGRANGE, J.-L.

1759: "Recherches sur la nature et la propagation du son," Miscellanea Taurinensia, I, 1-6.

LINDSAY, R. B.

1945: "Historical Introduction: The Development of Acoustics," in Strutt, J. W. (Lord Rayleigh), The Theory of Sound. 2nd edition, 2 vols. New York: Dover, I, v-xxxii.

1973: Acoustics: Historical and Philosophical Development. Stroudsburg: Dowden, Hutchinson and Ross.

LLOYD, L. S.

1954: "Sound," in Grove's Dictionary of Music and Musicians. 5th edition, Eric Blom, ed. London: Macmillan, VIII, 977-1000. LOULIÉ, É.

1696: Éléments ou principes de musique. Paris: Ballard. 
MAXHAM, R.

1976: "The Contribution of Joseph Sauveur to Acoustics." 2 vols. Ph.D. dissertation, University of Rochester.

MERSENNE, M.

1644: Cogita physico mathematica. Paris: Antoine Bertier.

PALISCA, C.

1961: "Scientific Empiricism in Musical Thought," in Rhys, H. H., ed., Seventeenth-Century Science and Art. Princeton: Princeton University Press, 91-137.

PERRAULT, C.

1680: Essais de physique ou receuil de plusieurs traitez touchant les choses naturelles, Vol. II. Paris: Jean-Baptiste Coignard.

RAMEAU, J.-P.

1971: Treatise on Harmony (1722). Translated by Philip Gossett. New York: Dover.

ROUHAULT, J.

1671: Traité de physique. Paris: Jean-Baptiste Coignard. SAUVEUR, J.

1736: "Système générale des intervalles des sons, et son application à tous les instruments de musique," Mémoires de l'Académie Royale des Sciences Année 1701. Paris: Gabriel Martin and Jean-Baptiste Coignard, 297-364.

SCHERCHEN, $\mathrm{H}$.

1950: The Nature of Music. Translated by William Mann. Chicago: H. Regnery Co.

SEMMENS, R.

1980: "Étienne Loulié as Music Theorist: An Analysis of Items in Ms. Paris, fonds français, n.a. 6355." Ph.D. dissertation, Stanford University.

TAYLOR, B.

1713: "De motu nervi tensi," Philosophical Transactions of the Royal Society, XXVIII, 26-32.

TOULMIN, S.

1961: "Science and the Arts," in Rhys, H. H., ed., Seventeenth-Century Science and the Arts. Princeton: Princeton Univessity Press, 3-28.

ZARLINO, G.

1573: Istitutione Armoniche. 2nd edition. Venice: Francesco dei Franceschi. 